\title{
1968, dos movimentos sociais à cultura
}

\author{
Robert Ponge*
}

Résumé: Cet article se penche sur le mouvement international de 1968, c'est-à-dire sur les événements et sur les mouvements qui agitèrent l'année 1968 et celles qui l'entourent (1967-1969). Il en étudie les dimensions politico-historiques et ébauche, très succintement, l'analyse de quelques aspects des dimensions culturelles. Il commence par chercher à comprendre les antécédents, les racines de 1968, ce qui provoqua son surgissement. Puis il passe rapidement en revue les principaux mouvements politicosociaux qui marquèrent 1968 dans le monde entier (après les USA, le Mexique, le Chili, l'Argentine, le Brésil, l'Allemagne de l'Ouest et l'Italie, il focalise particulièrement le Printemps de Prague et le mouvement de Mai 1968 à Paris). Ensuite, il étudie les acteurs du mouvement, leurs revendications et leurs espoirs. Il termine en signalant brièvement quelques aspects et quelques éléments des composantes culturelles de l'époque.

Palavras-chave: 1968; movimentos político-sociais; Primavera de Praga; Maio de 1968 francês; cultura.

O ano de 1968 conheceu, mundialmente, uma efervescência político-social excepcional. Foi um autêntico abalo sísmico. Com o famoso Maio francês e sua histórica greve geral, com a notável Primavera de Praga que despontou como a esperança na possibilidade de um socialismo autêntico eventos que se constituem nos dois movimentos de maior densidade política e social do ano, ambos prenhes de autênticas revoluções. Mas, também, com o estalo de uma miríade de importantes (por vezes, vultosas) mobilizações, nos quatro cantos do mundo. Sem sombra de dúvidas, 1968 foi um ano ímpar. Não por uma acumulação fortuita de coincidências, não por um puro acaso. Foi a expressão de que, naquele ano, "houve realmente um movimento internacional" (GROPPO, 1992, p. 17).

Um movimento internacional, com inevitável grau de heterogeneidade, que assumiu características específicas nos diferentes países. Mas que, para além da diversidade de suas formas nacionais, nem por isso deixou de possuir sua unidade, de ser mundial no seu conteúdo.

\section{As raizes do 1968}

O estopim, a unidade e o vulto das diversas lutas de 1968 residiram, antes de mais nada, em sua ascendência comum. O 1968 não surgiu do nada. Foi, pelo contrário, o produto de todo um período anterior de contestação mundial. ${ }^{1}$

Suas origens longínquas encontram-se no imediato pós-Segunda Guerra, que viveu um impressionante ascenso da mobilização e organização dos trabalhadores em numerosos países, a explosão das lutas de libertação nacional, a expropriação do capital na Europa do Leste, e a Revolução Chinesa.

Nos anos cinqüenta, na Europa, destacaram-se algumas mobilizações e paralisações nos regimes parlamentares do Ocidente. A novidade residiu no despertar da classe trabalhadora dos países do Leste Europeu, rebelada contra a ditadura burocrática e antipopular dos partidos stalinistas no poder. Em junho de 1953, com os levantes operários na Alemanha Oriental (repressão brutal); em 1956, com as Revoluções dos Conselhos Operários na Polônia e na Hungria (sangrenta repressão), e com greves e manifestações de rua na URSS (coibidas com prisões). No resto do mundo, a luta antiimperialista conheceu um considerável crescimento.

O maior impulso veio dos dez anos que antecederam 1968. O decênio principiou em grande estilo, com a vitória da Revolução Cubana, em 1959, e o ápice do processo de descolonização (a Grã Bretanha e a França perderam seus impérios). Presenciou, no mundo, uma radicalização das ações contra todas as formas de opressão e exploração, em particular, contra o imperialismo, salientando-se a América Latina e

\footnotetext{
* Robert Ponge é graduado e pós-graduado em Letras pela Universidade de Paris, doutor em Letras pela USP, professor titular do Instituto de Letras da UFRGS, onde leciona tradução e literatura; desenvolve pesquisas sobre tradução, sobre as relações Literatura/História e sobre surrealismo.

${ }^{1}$ Sobre o assunto, ver: ARRIGHI; HOBSBAWM; ver também RIBEIRO, Luiz Dario Teixeira. 1968 no mundo. In: PONGE, Robert (Org.). 1968, o ano das muitas primaveras. Porto Alegre: Unidade Editorial da Secretaria Municipal de Cultura da Prefeitura Municipal, 1998. p. 19-29; ver ainda RIBEIRO. O contexto de 1968. In: HOLZMANN, Lorena; SERRA PADRÓS, Enrique (Orgs.). 1968: contestação e utopia. Porto Alegre: Ed. da UFRGS, 2003. p. 19-26.

Organon, Porto Alegre, n 47, julho-dezembro, 2009, p.39- 55
} 
a luta dos jovens norte-americanos contra a guerra do Vietnã. $\mathrm{O}$ decênio desembocou em uma disseminação e multiplicação dos protestos: dos estudantes, da juventude, dos negros, das mulheres, dos trabalhadores e dos povos oprimidos. Tanto nos países capitalistas como no chamado Leste.

Os anos 1965, 1966 e 1967 devem ser vistos como precursores do 1968, prepararando-o. Falar do movimento internacional de 1968 remete, no mínimo, aos anos 1967-1969. Que surgiram como o resultado e a expressão maior de toda uma época, na qual - apesar de alguns reveses locais, que não conseguiram reverter a tendência geral - o movimento social, democrático e antiburocrático avançou, assegurou posições, conquistou outras, encontrando-se globalmente na ofensiva.

\section{8 no mundo}

Com o intuito de dar uma idéia de como o movimento de 1968 colocou em pauta a possibilidade de transformar o mundo, vou passar em revista as principais lutas do período, em alguns países, muito brevemente e sem nenhuma pretensão a ser exaustivo, de forma que, entre outros, não tocarei no Uruguai, na Holanda, na Bélgica, no Japão, na URSS e na China (cabendo, aliás, perguntar-se até que ponto a China de Mao e a chamada Revolução Cultural encontravam-se em sintonia com a movimentação antiautoritária e antiburocrática da juventude do resto do mundo?). Inicio com o continente americano. Salto a seguir para a RFA e a Itália. ${ }^{2}$ Finalmente, debruço-me, com maior profundidade, sobre a Praga da Primavera dos povos e sobre a Paris do memorável Maio francês.

\section{Estados Unidos}

Nos anos sessenta, nos EUA, destacam-se a luta contra a guerra do Vietnã, que agita os campi universitários (sit-ins/sentadas, ocupações) e o combate contra a discriminação racial, que convulsiona os bairros negros e espalha-se para as ruas. Em 1967, as ações multiplicam-se, o verão quente deixando um saldo de milhares de incêndios nos guetos negros, algumas dezenas de mortos e numerosos feridos e presos. Em 04 de abril de 1968, Martin Luther King, a maior liderança do movimento negro não violento, é assassinado em Memphis, deflagrando uma explosão de revolta e uma série de conflitos. Mas o movimento negro não consegue saldos qualitativos duráveis, o que deixa um certo sabor de frustração. Será, por outro lado, preciso esperar 1973 para poder celebrar o fim da guerra do Vietnã.

\section{México}

Em 22 de julho de 1968, na Cidade do México, a extrema violência da intervenção policial em um conflito entre grupos estudantis rivais provoca uma mobilização que deságua, três dias depois, em uma passeata de cinqüenta mil estudantes. ${ }^{3}$ Em reação, o governo do PRI (partido quase único) lança a repressão contra o movimento e contra a imprensa oposicionista. O que suscita barricadas nos campi (antes de mais nada no campus central da Universidade Nacional Autônoma do México - a famosa UNAM). As barricadas são seguidas de prisões. A resposta não se faz esperar: no dia 5 de agosto, começa a greve geral estudantil. Em documentado estudo, o professor Enrique Serra Padrós explica:

\footnotetext{
"Novas marchas se sucederam e o número de presos, mortos e feridos tomou proporções alarmantes. O reitor da UNAM, Javier Barros Sierra, liderou grupos de intelectuais e professores denunciando a barbárie estatal. No 12 de agosto marcharam 200 mil pessoas, e no dia 27, a praça do Zócalo foi tomada por centenas de milhares de pessoas que substituíram a bandeira mexicana por outra, vermelha e preta." (SERRA PADRÓS, 1998, p. 176)
}

Em meados de setembro, dez mil soldados ocupam os campi da UNAM, do IPN e de outras universidades do interior. Incapaz de retomar os campi, o movimento estudantil está estagnando. Mas, comenta Enrique Serra Padrós, “o pior estava por acontecer”:

"No dia dois de outubro de 1968, seis mil estudantes estavam concentrados na Praça dos Três Poderes, ao lado da Igreja de Santiago Tlatelolco, Cidade do México. Às 18 horas, após reafirmarem o caráter pacífico do ato e o respeito dos preceitos constitucionais, preparavam-se para encerrar a concentração. Entretanto, o exército rodeara completamente a praça. Centenas de

\footnotetext{
${ }^{2}$ Sobre o assunto, além da bibliografia já citada, tomo basicamente como referência: para as Américas, SERRA PADRÓS, Enrique. De Berkeley a Tlatelolco: o 68 nas Américas. In: PONGE (Org.). Op. cit. 1998. p. 69-80; para a Europa (Alemanha e Itália), RIBEIRO. Art. cit. 1998. p. 19-29.

${ }^{3}$ Sobre 1968 no México, ver: SERRA PADRÓS. Art. cit. 1998; ver, também, SOUZA, Susana Bleil de. América Latina: insurreição, resistência e repressão. O México rebelde e o Uruguai da repressão. In: HOLZMANN; SERRA PADRÓS (Orgs.). Op. cit. 2003. p. 67-77.
} 
falcões, militantes paramilitares de extrema direita, haviam-se infiltrado no meio da multidão. Às 18 horas e quinze minutos luzes de bengala deram o sinal. Os falcões, com luvas brancas na mão esquerda para identificar-se, abriram fogo contra os oradores que estavam no terceiro andar do edifício Chihuahua. Os jornalistas e fotógrafos presentes foram encerrados num local do edifício até tudo terminar. Unidades de assalto, carros com metralhadoras, helicópteros e até tanques foram utilizados na selvagem repressão. Há informações de que uns cinco mil soldados participaram do massacre. A praça foi atacada desde todos os flancos. O tiroteio ininterrupto durou duas horas; até altas horas da madrugada continuou a caçada humana. Membros do Conselho Nacional de Greve foram fuzilados no porão do edifício Chihuahua. A dimensão do crime é desconhecida. Os remanescentes do Conselho informaram a prisão de uns dois mil estudantes e que uns 500 tinham sido gravemente feridos; calculavam em 200 o número de mortos. Publicações recentes apontam entre 100 e 500 estudantes assassinados. Tal desconhecimento deve-se ao fato de que os cadáveres provavelmente foram incinerados ou jogados ao mar. Os jornalistas, quando libertados, viram muitos soldados limpando o sangue espalhado por toda a praça. Centenas de famílias procuraram pelos filhos desaparecidos. Como era de esperar-se, não obtiveram resposta." (SERRA PADRÓS, 1998, p. 177)

O movimento estava exausto, condenado a encerrar as mobilizações e, relembra Enrique Serra Padrós, "dez dias após o Massacre de Tlatelolco", o presidente do México "inaugurava os Jogos Olímpicos, símbolo da paz entre os povos" (SERRA PADRÓS, 1998, p. 177)

\section{Chile, Argentina}

Em 1967, no Chile, acontecem mobilizações pela reforma universitária, que continuam em 1968, ano de crescimento da agitação social e das greves de trabalhadores: está se desenvolvendo o movimento democrático e social que, em 1970, levaria o socialista Salvador Allende, candidato da Frente Popular, à presidência da República.

Em 29 de junho de 1966, na Argentina, inicia a ditadura do general Onganía. A resistência democrático-popular consegue ser efetiva, embora com altos e baixo. O ponto culminante da luta ocorre em maio de 1969, no bojo de diversos movimentos de mobilizações e greves disseminados em diversas províncias do país. No dia 29, em resposta ao chamado à greve geral lançado pela CGT local, os estudantes e trabalhadores de Córdoba ocupam o centro da cidade, expulsam as forças policiais. $\mathrm{O}$ Cordobazo controla a cidade durante dois dias. No dia 31, as tropas militares conseguem retormar o controle da cidade e impor violenta repressão. Mas o Cordobazo entrou para a história e a memória do movimento operário e democrático internacional. ${ }^{4}$

Brasil

No Brasil da ditadura militar (instaurada em 1964), destacamentos militares invadem o restaurante do Calabouço, no Rio de Janeiro, disparam contra os estudantes, matando Édson Luis Lima Souto. No dia seguinte, 29 de março, sessenta mil pessoas acompanham o enterro, manifestando. A repressão responde com violência, a cidade do Rio sendo palco de vários dias de enfrentamentos. ${ }^{5}$

No mês de abril, eclode a histórica greve de Contagem, MG: dezesseis mil trabalhadores paralizam o trabalho, conseguindo um abono salarial de dez por cento.

Em São Paulo, SP, na festividade do dia $1^{\circ}$ de maio, realizada na praça da Sé, o governador de São Paulo e demais autoridades são vaiados e enxotados do palanque, o qual é queimado.

No dia 26 de junho, são realizadas manifestações estudantis e populares nos principais centros urbanos do país. Cinqüenta mil pessoas manifestam no Recife. No Rio de Janeiro, é realizada a famosa Passeata dos Cem Mil!

Em 16 de julho, começa a greve dos metalúrgicos de Osasco, SP, que recebe a adesão de dez mil trabalhadores. Tropas militares são enviadas, invadem as fábricas, prendem os grevistas; o presidente do Sindicato é obrigado a fugir. No quinto dia, a paralisação é quebrada. É o começo do fim do 1968 brasileiro!

\footnotetext{
${ }^{4}$ Sobre o Cordobazo, ver: BLANCO, Fernando. El Cordobazo argentino. In: HOLZMANN; SERRA PADRÓS (Orgs.). Op. cit. 2003. p. 79-88.

${ }^{5}$ Sobre o Brasil em 1968, ver: MAESTRI, Mário. Brasil, 1968: o assalto às núvens. In: PONGE (Org.). Op. cit. p. 83-91; e ainda Idem. Brasil, 1968: o assalto ao céu, a descida ao inferno. História: Debates e Tendências, revista do PPG em História da Universidade de Passo Fundo - UPF, vol. 8, n 1, jan./jul. 2008. ISSN : 1517-2856. Publicação impressa e eletrônica. Passo Fundo, RS: Editora da UPF, publicada no $1^{\circ}$ semestre de 2009, p. 13-27. Disponível na rede, na página: http://www.ppgh.upf.br/ Ver também as bibliografias às quais ambos trabalhos remetem.
} 


\section{Alemanha Federal}

Em abril de 1967, a SDS (Liga dos Estudantes Socialistas Alemães) organiza um protesto contra a visita do vice-presidente estadunidense à República Federal Alemã (RFA, também conhecida como Alemanha Ocidental). Ao final do mesmo ano, manifestam contra a visita do xá do Irã (regime autoritário e repressor). Há violenta repressão policial (com a morte de um estudante).

Em fevereiro de 1968, a SDS organiza, em Berlim, um Congresso Internacional contra a Guerra do Vietnã e convoca uma manifestação, que o governo procura proibir por todos os meios.

Em 11 de abril, Rudi Dutschke, a principal liderança da SDS, sofre um atentado (duas balas no cérebro), que provoca revoltas e levantes da juventude. Os prédios dos jornais do grupo Springer (que destacava-se por sua permanente campanha de vis ataques contra a SDS) são cercados e hostilizados em várias cidades; o de Berlim é incendiado.

Mas, percorrida por numerosas tensões e contradições, a SDS não consegue encontrar continuidade e horizonte, dissolvendo-se em 1969.

Itália

Na Itália, as lutas estendem-se de 1967 até 1969 (o movimento sendo denominada de maio rastejante), expressando-se através da contestação estudantil (com ocupação de universidades) e de greves de trabalhadores.

\section{A Primavera de Praga}

Em meados de 1967, na Tcheco-Eslováquia, vêm à tona manifestações de descontentamento contra a ditadura do partido único, a censura, a repressão, a planificação burocrática e as relações economicamente desiguais impostas pela tutela da URSS. Acabam provocando, nas cúpulas do Partido Comunista TchecoEslovaco (PCT), choques abertos entre a ala satisfeita com a situação vigente e uma corrente levemente modernizante. ${ }^{6}$

Em janeiro de 1968, para conter o clamor popular, Aleksander Dubcek (jovem e desconhecido hierarca do PC eslovaco) é chamado para substituir Antonin Novotny na secretaria geral do PCT (mas este continua na presidência da República).

Percebida pela população como um sinal de abertura, essa substituição impulsiona a continuidade do debate (inclusive no próprio PCT) e das manifestações, estimula a expressão das reivindicações populares bem como o aparecimento e a disseminação de diversas formas de organização independente (assembléias, organizações profissionais e culturais, etc.). A Primavera de Praga está derretendo o gelo burocrático.

Porém, a facção de Novotny resiste, atacando tanto a oposição interna ao PCT como a oposição popular. O que, por sua vez, aguilhoa o movimento reivindicatório e antiburocrático, levando a ala liberalizante de Dubcek a promover, em março de 1968, uma limpeza limitada nas máquinas estatal e partidária (Novotny é removido da presidência da República).

Não é o suficiente para conter o movimento popular, que continua seu avanço. Assustado, o Kremlin começa os preparativos para a invasão da Tcheco-Eslováquia pelas tropas do Pacto de Varsóvia. E utiliza como pretexto a publicação do Manifesto das duas mil palavras (documento que questiona o regime burocrático e o partido único) e o recrudescimento das manifestações contra as indecisões de Dubcek frente às ingerências de Moscou à soberania tcheco-eslovaca.

$\mathrm{Na}$ noite de 20 a 21 de agosto de 1968, é desencadeada a intervenção armada. Dubcek e seus colaboradores são presos, levados à URSS. Pressionados, inclusive fisicamente, cedem às imposições de Moscou.

Entretanto, a força da resistência popular obriga Moscou a um aparente recuo: liberta Dubcek. Foi, porém, sob condições: este se comprometeu em ser o agente da normalização stalinista. Nos meses seguintes, ele se empenha em fazer retroceder as reformas, em depurar as máquinas estatal e partidária ao gosto do Kremlin, restrigir as liberdades, proibir as manifestações públicas. Justifica essas medidas como necessárias para afastar o risco de uma segunda intervenção.

Em janeiro de 1969, o suicídio do estudante Jan Palach (em protesto, ateia fogo ao próprio corpo em praça pública) causa uma comoção geral, desencadeando novas manifestações que... não conseguem reverter o processo de normalização.

\footnotetext{
${ }^{6}$ Esta análise inspira-se em PONGE, Robert; ZEMOR, Fernando. Da primavera de Praga às barricadas de Paris. In: HOLZMANN; SERRA PADRÓS (Orgs.). Op. cit. 2003. p. 43-51. Para uma análise mais desenvolvida, ver ZEMOR, Fernando. A Primavera de Praga: o processo político. In: PONGE (Org.). Op. cit. 1998. p. 39-45, e a bibliografia à qual remete.

Organon, Porto Alegre, $\mathrm{n}^{\circ}$ 47, julho-dezembro, 2009, p.39- 55
} 
Em março, uma nova onda de importantes manifestações é reprimida com censura, demissões, indiciamentos: Dubcek mostra que está no controle da situação.

Ingrato, o Kremlin descarta-o em abril: é substituído, na liderança do PCT, por Gustav Husak que leva adiante a segunda etapa da normalização, completando-a com a volta ao statu quo ante!

França: Maio de 1968

Em 1958, De Gaulle chega à chefia do governo francês, festejado como um salvador. Em 1963, seu governo implanta um plano de estabilização de nítidos contornos monetaristas, que suscita insatisfação, provocando resistência, movimentos de protesto. As greves e manifestações aumentaram no início de 1968. Mais numerosas nas universidades, embora com amplitude restrita. ${ }^{7}$

O governo provoca a explosão

De Gaulle está muito seguro de sí, insensível à crescente insatisfação. Interpreta a incipiente contestação como obra de grupúsculos infiltrados, à soldo de interesses escusos. Decide cortar o mal pela raiz, com punições exemplares contra líderes escolhidos à dedo.

Em 3 de maio, o movimento estudantil responde com um modesto comício na Universidade de Paris (a Sorbonne). O ministro reage com a invasão e ocupação policial do prédio e a prisão dos manifestantes. Tais medidas suscitam imediatas e imprevistas passeatas de protesto, espontâneas. Optando pelo confronto, o governo reprime com brutalidade. É o detonador da explosão.

A União Nacional dos Estudantes da França (UNEF) convoca a greve geral estudantil. O sindicato nacional dos docentes do ensino superior (SNESup) dá seu apoio ao protesto. As manifestações crescem e se sucedem diariamente. A ferocidade da ação policial contra os estudantes suscita repúdio ao governo, solidariedade aos estudantes, amplia as manifestações e pressiona as centrais sindicais a convocar, junto com a UNEF e o SNESup, uma grande paralisação nacional em 13 de maio.

\section{Começa a greve geral}

A incomum magnitude das manifestações daquele dia (em Paris, uma passeata com mais de 500 mil pessoas) dá confiança aos trabalhadores e serve de trampolim para a deflagração, no dia seguinte, de greves reivindicativas e sua disseminação. Começa a greve geral que fez passar o mês de maio de 1968 para a história: a maior de todos os tempos, com dez milhões de grevistas.

Apesar da omissão das centrais sindicais, o processo de generalização das greves cria uma pauta nacional de reivindicações (jornada de 40 horas semanais, sem redução salarial; aposentadoria aos 60 anos; revogação dos decretos-leis prejudiciais ao sistema público de saúde e previdência; etc.).

Por outro lado, a amplidão da greve geral apresenta um sentido político que ultrapassa o terreno meramente sindical, negando qualquer legitimidade ao governo ("Fora De Gaulle!", gritam os manifestantes).

Questões da greve geral

Como se comportam as principais forças que se definem como de esquerda? Sua atuação é, no mínimo, marcada pela passividade e dubiedade.

A Federação da Esquerda Socialista (FGDS, precursora do atual PS) e o Partido Comunista Francês (PCF) colocam que De Gaulle deve "ir embora", porém sem apontar para qualquer ação concreta. Ficam aguardando que ele se demita por livre e espontânea vontade.

Por sua vez, as direções das centrais sindicais negociam com o governo, reconhecendo-lhe a legitimidade que os grevistas lhe negam. Ainda por cima, não assumem como pedra de toque a pauta nacional de reivindicações. O resultado é uma "minuta de acordo" que ficou muito aquém das exigências dos trabalhadores, tanto que é veementemente recusada pelos grevistas.

A terminante rejeição da "minuta" liga, de maneira ainda mais íntima, os dois aspectos da greve: a pauta reivindicativa e a exigência de saída de De Gaulle. Vincula ambos, pois (além de ser responsável pela política econômica e social do decênio e pela repressão das últimas semanas) é esse mesmo governo que nega, agora, o atendimento das reivindicações. Entretanto, esta estreita união não é assumida, nem

\footnotetext{
${ }^{7}$ Para una análise mais desenvolvida, ver PONGE. Maio de 1968: a greve geral que abalou a França. História: Debates $e$ Tendências, revista do PPG em História da Universidade de Passo Fundo - UPF, vol. 8, nº 1, jan./jul. 2008. ISSN : $1517-2856$. Publicação impressa e eletrônica. Passo Fundo, RS: Editora da UPF, publicada no $1^{\circ}$ semestre de 2009, p. 85-101. Disponível na rede, na página: http://www.ppgh.upf.br/
} 
pelas centrais, nem pelos partidos de esquerda. Ficam esperando para ver o que o presidente da República vai fazer.

\section{A esquerda aceita a jogada de De Gaulle}

De Gaulle estava vacilando e tropeçando. No entanto, a imobilidade da esquerda dá-lhe fôlego, que ele aproveita com o firme discurso de 30 de maio: promete a realização de eleições legislativas, desde que seja encerrada a greve; senão, restabelecerá a ordem pela força, a qualquer custo.

A FGDS, o PCF e as centrais concordam que as eleições são mesmo a saída, o caminho para derrotar De Gaulle e para obter as reivindicações. Os partidos abandonam a greve à sua sorte, apostando no seu fim, em prol da campanha eleitoral. As centrais desenvolvem as negociações de maneira fracionada, por empresa ou ramo, visando também o término da greve; as reivindicações da pauta fundamental são abandonadas e remetidas à Assembléia Legislativa a ser eleita. Corretamente, o historiador Georges Lefranc constata: "Doravante, reivindicações sociais e atividade política [i.e., político-partidária] vão se distanciar" (LEFRANC, 1969, p. 242). De fato, as centrais sindicais e os dois grandes partidos de esquerda estão separando o que o desenvolvimento da greve geral tinha unido. Cada um intervém no seu terreno específico, porém uma mesma linha perpassa sua atuação: tudo para garantir as eleições.

Resultado das urnas? Uma enxurrada de votos nos gaullistas, que fazem o melhor resultado de toda sua história. O PCF e a FGDS, somados, perdem cem cadeiras. Por que?

As eleições foram uma jogada inteligente de um presidente enfraquecido para que a esquerda aceitasse abrir mão da arma que fazia sua força, trocando-a por um terreno que poderia não ser tão desfavorável ao gaullismo. Ainda mais com a greve terminada, com a máquina governamental, a mídia e todo o establishment a torcer ativamente pelo sucesso dos partidos da ordem.

Em suma, depois de enfraquecer a greve com a atomização das negociações, o PCF, a FGDS e as centrais sindicais curvaram-se diante de De Gaulle, aceitando que este último desse as cartas. Ele, que profetizara o caos se a greve continuasse, apareceu como um homem forte capaz de trazer saídas, garantir a ordem, evitar o abismo. O eleitorado flutuante votou nele. Na verdade, eram eleições feitas sob medida por e para De Gaulle: ele as convocou, as organizou, as garantiu, as realizou. Foi o inconteste vencedor.

\section{O 1968 morreu?}

Mundialmente, o 1968 político-social não se evapora espontaneamente no ar. É desfeito. Em certos países, sufocado pela repressão aberta: México, Brasil, etc. Em outros, desarticulado politicamente pelas elites, com a colaboração - maior ou menor, passiva ou ativa - das direções sindicais e/ou da esquerda tradicional (a este respeito, a França oferece o exemplo antológico).

No final de 1969, a erupção vulcânica de 1968 pode ser considerada como encerrada. A "normalidade" voltou. Tudo regressou à estaca zero? Abre-se uma época de reação? Neste tocante, não se deve generalizar a conjuntura do Brasil, onde, no final de 1968, com o AI 5, a ditadura dá mais um aperto no fechamento. Que durará cerca de dez anos. Retrospecto nada alentador.

Outra é a situação mundial. Foi preservado o statu quo, mas com extrema dificuldade. Os governantes têm a plena consciência de que o decênio seguinte abre-se sob o signo de um equilíbrio instável. O vulcão não está morto, nem domado, somente descansando ou, quem sabe?, apenas aguardando novas oportunidades. O que os anos 70 virão confirmar: derrota dos EUA no Vietnã; Revolução dos Cravos no Portugal; derrubada de Somoza, na Nicaragua, e do Xá, no Irã (duas das mais antigas ditaduras), etc. Até Ronald Reagan e Margaret Thatcher, por volta de 1979, conseguirem retomar a iniciativa e impulsionar efetivamente a marcha conquistadora do chamado neoliberalismo (cuja análise não cabe neste trabalho).

\section{Os atores e seus anseios}

1968 não se reduz ao movimento estudantil. Mesmo assim, a grande protagonista, em nível mundial, é a juventude - a "chama da revolução" (Rosa Luxemburgo). Em suas mais diversas camadas universitária, secundarista, operária, camponesa - e com suas diversas cores de pele, os jovens, de 15 a 30 anos, de ambos os sexos, manifestam. Por que a juventude? Talvez porque a Segunda Guerra ceifou a vida de milhões de adultos e porque o final da mesma suscitou um estrondoso baby-boom que começou, a partir de 1959, a despejar os jovens, em profusão, nas escolas e no mercado de trabalho.

Outrossim, 1968 presencia, em vários países, a intervenção da classe trabalhadora e da população em geral. Na França e na Tcheco-Eslováquia, de maneira decisiva, proporcionando um salto na densidade e alcance dos movimentos. E ainda no Japão, Chile, Argentina, Brasil, Itália, URSS, etc.

Para além da variedade das reivindicações específicas, de país a país, quais palavras de ordem se repetem internacionalmente? No países capitalistas, a luta antiimperialista se faz sempre presente, a 
denúncia da intervenção estadunidense no Vietnã aparecendo como a referência fundamental. A principal característica consiste, entretanto, na recusa em sofrer as conseqüências das "reestruturações" reorganização da produção, reformas universitárias, etc. - impostas pela lógica do capital. Destacam-se também as mobilizações contra as diversas formas de opressão, quer seja contra as violências policiais, contra os regimes ditatoriais ou contra a discriminação racial. Nos países do Leste, o eixo central reside na exigência de democracia, o que abrange tanto a resistência às "normas" impostas pelas ditaduras stalinistas como o reclamo do direito de livre organização sindical e partidária.

De Paris a Praga e Moscou, passando pela Cidade do México, Rio, Córdoba, Tóquio, Madri, Washington etc., os manifestantes se unem em um sonoro brado de protesto contra os sistemas de exploração, dominação e manipulação vigentes. No Leste, rejeita-se o stalinismo, em nome de um socialismo verdadeiro, com democracia. No resto do planeta, rejeita-se o capitalismo - em nome de um anticapitalismo nem sempre preciso -, e suspeita-se crescentemente do modelo dito soviético de regime, que aparece cada vez mais anti-socialista. A qualidade superior do 1968 reside na poderosa conjunção que realiza - do movimento social nos países capitalistas e do movimento antiburocrático no Leste -, abrindo um novo período na conjuntura.

\section{A cultura em 1968}

Não é possível apresentar, aqui, um quadro completo do mundo da cultura nos anos 1967-1969 (este é extremamente diverso, heterogêneo, percorrido de tensões, oposições, contradições). Limito-me em tentar apontar alguns dos elementos que, no mundo ocidental (não disponho, neste respeito, do conhecimento necessário para poder comentar as outras realidades), expressam, em algum grau e medida, os anseios de rebeldia, contestação e transformação que estão no âmago dos processos socio-políticos de 1968.

Além do movimento político-social (no qual intervêm as mais diversas tendências políticas de esquerda), a ebulição de 1968 suscita espaços de festa (atividades de lazer, recreativas, divertimentos, jogos...), programações culturais (palestras, mesas-redondas, debates, espetáculos, exposições...) bem como uma caminhada de reflexão, crítica, contestação e experimentação em todos os terrenos, tanto teórico-intelectual como nas vivências ou na cultura e nas artes: os modos de se comportar, de se relacionar, de viver, de pensar, de sentir, de se expressar são debatidos, questionados, revistos, modificados...

No terreno das vivências, questiona-se, antes de mais nada, o modelo da american way of life, o moralismo estreito e repressor, o establishment (o sistema), os chavões do pretenso senso comum, etc. E procura-se saídas, soluções, caminhos (não poucas vezes confusamente - mais não poderia ser de outro modo, pois não há à mão nenhum roteiro com o mapa da mina!)

\section{As influências e os inspiradores}

Esses e outros questionamentos não surgem do nada; decorrem, em parte, das profundas modificações geradas na sociedade pela universalização da dominação capitalista (isto é, da sociedade industrial e do reino avassalador da mercadoria) e das numerosas contradições inerentes a essa.

Tampouco, os questionadores vêm-se na obrigação de reinventar a roda. Apoiam e alimentam sua reflexão em ensinamentos trazidos por figuras do passado que revolucionaram alguma área da atividade humana e por todos aqueles que procuraram (ou procuram) fazer frutificar tais lições.

Quem são eles? A lista começa por um trio histórico: Marx, Nietzsche, Freud. E pelos grandes teóricos do socialismo e do comunismo, sejam eles oriundos do anarquismo (Bakunine, Kropotkine) ou do marxismo (Marx e Engels, Lenin, Rosa Luxemburgo, Trotski, Che Guevara, Mao - sendo que, nos anos 1970 e posteriores, a estrela deste último não parará de cair em decorrência das dúvidas, desilusões e frustrações geradas pelos descaminhos da Revolução Chinesa, inclusive de sua pretensa Revolução Cultural).

Há também a redescoberta dos chamados socialistas utópicos, um imenso crescimento do interesse por Gramsci e pelo Georg Lukács de História e consciência de classe (e, novamente, por Rosa Luxemburgo, Trotski, Guevara), e, ainda, pelas contribuições daqueles que procuram colaborar ao enriquecimento, atualização e vivificação do marxismo contemporâneo: sejam eles militantes e teóricos (Pierre Broué, Ernest Mandel), sejam eles intelectuais, como Perry Anderson, Kostas Axelos (Marx, pensador da técnica), Louis Althusser (cuja estrela decairá bastante a partir dos anos oitenta, seu pretenso corte epistemológico não resistindo ao teste do tempo), Jean-Paul Sartre, Frantz Fanon e, sobretudo, Wilhelm Reich e Herbert Marcuse. O freudo-marxista e sexólogo Wilhelm Reich (1897-1957, autor, entre outros títulos de A função do orgasmo, de $O$ surgimento da moral sexual, de A psicologia de massas do fascismo) foi um homem apaixonadamente engajado na denúncia da miséria sexual e na militância pela 
emancipação sexual dos seres humanos, particularmente dos jovens e das mulheres. Por sua vez, Herbert Marcuse, professor universitário em uma universidade norte-americana, analisa em seus livros a alienação no mundo contemporânea ( $A$ ideologia da sociedade industrial, $O$ homem unidimensional); independentemente do grau de acerto de suas teorias e da medida de sua real influência sobre as mobilizações de 1968, é então o maior ícone vivo (Reich faleceu dez anos antes) da contestação intelectual radical nos Estados Unidos e, até certo ponto, no resto do mundo ocidental.

$\mathrm{Na}$ lista das influências e dos inspiradores, não podem ser esquecidos, entre outros:

- na Europa, a dúvida e o negativismo do dadaísmo (aparecido em 1916), bem como o não-conformismo absoluto do surrealismo que, desde 1925, vem propondo lutar simultaneamente para mudar a vida (com Rimbaud) e transformar o mundo (com Marx);

- o grito e movimento da negritude lançados, em 1939, pelos poetas Léopold Sédar Senghor e Aimé Césaire (negritude que, em 1952, encontrou um excepcional embasamento teórico em Pele negra, máscaras brancas de Frantz Fanon);

- nos EUA, a anticonformista geração Beat, que surgiu no imediato pós-Segunda Guerra Mundial com Jack Kerouac, John Clellon Holmes e Allen Ginsberg.

\section{Os lemas de 1968}

Quais são as idéias-chaves de 1968? Embora seja temerário querer definir idéias centrais para um conjunto de movimentos tão numerosos e diversos, pode-se, mesmo assim, apontar algumas palavras de ordem, pichadas (hoje: grafitadas!) anonimamente nas paredes da Paris do Maio de 1968, que resumem, sintetizem os anseios básicos que impulsionem a(s) revolta(s), a(s) luta(s):

- por um lado, a dimensão antiautoritária, antirepressora de 1968: É proibido proibir!

- por outro lado, a imensa aspiração ao enterro do velho sistema explorador, opressor, alienador, podre, e o desejo de mudanças e transformações profundas, radicais: ou seja, o chamado a colocar A imaginação no poder! E também: Acreditem em seus sonhos! E ainda: Sejam realistas: peçam o impossível!

\section{Dos movimentos político-sociais à música}

Em 1968, existiram movimentos que deram uma forte e grande expressão cultural aos combates políticos, embora de forma muito diversa e desigual, segundo os países. Pode-se, aqui, apontar pelo menos três desses.

Designa-se como hippies (também chamados de flower children e, por antífrase, de flower power) um movimento pouco definido, extremamente difuso, espontaneísta (sem estruturas organizativas nem centralização ou programa preciso), que, nos EUA (com repercussões internacionais), procede do estado de espírito (ou intenção, nem sempre concretizada ou persistentemente perseguida) de criar comunidades alternativas, contraculturais, tendo como única plataforma Paz e Amor! A postura hippie é uma das expressões da luta contra a guerra do Vietnã e pelo boicote à mesma (escapando do alistamento obrigatório pela fuga ao Cánada, Suécia ou outros países). O musical Hair (estreado em 1967, com longo sucesso de público) dá uma materialização artístico-teatral a ambos o movimento hippie e o combate contra a guerra, corporificação que será sumamente amplificada pelo filme eponímico (1979, um sucesso mundial de bilheteria). Outra expressão fronteiriça ao espírito hippie é o festival de Woodstock (1969, anunciado como Uma exposição aquariana: três dias de Paz e Música), que repercute amplamente no mundo por reunir cerca de quinhentos mil jovens, mas também pela difusão, a partir de 1970, da gravação ao vivo (um volume de dois discos) e do filme homônimo (ambos são sucessos de vendas e de bilheteria). Já que estamos no terreno da música, cabe registrar que existe, nesses anos, um forte gênero de música posicionada, ou engajada (que esteve presente em Woodstock), música de protesto cujas figuras históricas e lendárias são Woody Guthrie (falecido em 1967) e Pete Seeger. Além deste, os principais nomes, em 1968, são Joan Baez, Bob Dylan, Peter Paul and Mary, entre outros.

Ainda nos EUA, o movimento Black Power (Poder Negro) dá uma representação política (com várias e cambiantes expressões político-partidárias) à negritude criada por Senghor e Césaire em 1939. Por sua vez, o Black Power tem diversas expressões no terreno artístico, inclusive na música pop (ou pop-rock) negra, a Black Music, que é, também, música de protesto com, por exemplo, Say it loud: I'm Black and I'm Proud!, cantado por James Brown (Diga bem alto: sou negro e tenho orgulho!).

A música dita de protesto ou posicionada não é e nunca foi privilégio dos EUA: ela existe, vive e se posiciona em todos os países. Não é diferente no Brasil dos anos 1968, Brasil da ditadura, em que os shows da MPB e os festivais da canção tornam-se palcos de expressão (portanto, manifestação, embates) política, às vezes explícita, às vezes tão subentendida e indireta que a censura nem consegue suspeitar, embora o público saca tudo e vibra. O historiador Mário Maestri relembra: 
"País de poucos leitores, com a televisão engatinhando, o combate cultural enfurecia, quando se tratava da música popular. Apenas parcialmente inconscientes do papel que cumpriam, Roberto Carlos, Erasmo Carlos e a turma da Jovem Guarda pregavam a despolitização e só pediam "que você me aqueça neste inverno e que tudo mais vá para o inferno". A esquerda dominava totalmente o campo, com uma seleção que só aceitava craques: Caetano, Chico, Elis Regina, Jair Rodrigues, Gilberto Gil, Geraldo Vandré, Vinicius de Moraes. Quando dos festivais da canção, a disputa politizada transformava-se em uma quase batalha campal. Através da música, debatiam-se os projetos para o futuro do país. Numa época sem cerimônias, o público levantava-se, iconoclasta, contra os monstros sagrados que construía, se ousassem sair da linha ou do que se pensava que fosse a linha.

$$
[\ldots]
$$

Em 28 de setembro [de 1968], no Terceiro Festival Internacional da Canção, da Globo, em São Paulo, acompanhado pelos Mutantes, Caetano Veloso apresentou a música É proibido proibir, vestido com roupas de plástico colorido, com colares exóticos no pescoço, enquanto um jovem norte-americano, ainda mais psicodélico, saltava e berrava no palco, como parte da coreografia. Da competição participava a canção Pra não dizer que não falei de flores, de Geraldo Vandré, que se tornaria uma espécie de hino da resistência.

As históricas vaias que o cantor recebeu certamente interpretavam a consciência do público, formado quase exclusivamente por jovens, do distanciamento de parte da intelectualidade da resistência direta. Mais tarde, Elis Regina cantaria "eu quero uma casa no campo, do tamanho ideal [...]". A defecção de seu companheiro Jair Rodrigues seria ainda mais bucólica. Porém, nos anos seguintes, alguns artistas continuariam segurando a peteca e cutucando a onça com vara curta. Entre eles, destacar-se-ia Chico Buarque, às vezes com um despretensioso roquezinho - "você não gosta de mim, mas sua filha gosta" - ou com composições clássicas como Fado tropical.” (MAESTRI, 1998, p. 86 e 88-89) ${ }^{8}$

A transcrição é um pouco longa, mas creio ser absolutamente necessário citá-la. E não apenas porque continuo gostando de Pra não dizer que não falei de flores!

\section{Bibliografia}

ARRIGHI, Giovanni. O longo século XX. São Paulo: UNESP, 1996.

GROPPO, Bruno. Mai 68 dans le contexte international. In: MOURIAUX, René et alii. 1968: exploration du Mai français, tome 1: Terrains. Paris: L'Harmattan, 1992. p. 12-24.

HOBSBAWM, Eric. Era dos extremos: o breve século XX (1914-1991). Trad. do inglês por Marcos Santarrita. São Paulo: Companhia das Letras, 1995.

HOLZMANN, Lorena; SERRA PADRÓS, Enrique (Orgs.). 1968: contestação e utopia. Porto Alegre: Ed. da UFRGS, 2003.

LEFRANC, Georges. Le Mouvement syndical: de la Libération aux événements de mai-juin 1968. Paris: Payot, 1969.

MAESTRI, Mário. Brasil, 1968: o assalto às nuvens. In: PONGE, Robert (Org.). 1968, o ano das muitas primaveras. Porto Alegre: Unidade Editorial da Secretaria Municipal de Cultura da Prefeitura Municipal, 1998. p. 83-91.

MAESTRI, Mário. Brasil, 1968: o assalto ao céu, a descida ao inferno. História: Debates e Tendências, revista do PPG em História da Universidade de Passo Fundo - UPF, vol. 8, nº 1, jan./jul. 2008. ISSN : 1517-2856. Publicação impressa e eletrônica. Passo Fundo, RS: Editora da UPF, publicada no $1^{\circ}$ semestre de 2009, p. 13-27. Disponível na rede, na página: http://www.ppgh.upf.br/

MOURIAUX, René et alii. 1968: exploration du Mai français, tome 1: Terrains. Paris: L'Harmattan, 1992.

PONGE, Robert (Org.). 1968, o ano das muitas primaveras. Porto Alegre: Unidade Editorial da Secretaria Municipal de Cultura da Prefeitura Municipal, 1998.

PONGE, Robert. Maio de 1968: a greve geral que abalou a França. História: Debates e Tendências, revista do PPG em História da Universidade de Passo Fundo - UPF, vol. 8, nº 1, jan./jul. 2008. ISSN : 1517-2856. Publicação impressa e eletrônica. Passo Fundo, RS: Editora da UPF, publicada no $1^{\circ}$ semestre de 2009, p. 85-101. Disponível na rede, na página: http://www.ppgh.upf.br/

SERRA PADRÓS, Enrique. De Berkeley a Tlatelolco: o 68 nas Américas. In: PONGE, Robert (Org.). 1968, o ano das muitas primaveras. Porto Alegre: Unidade Editorial da Secretaria Municipal de Cultura da Prefeitura Municipal, 1998. p. 69-80.

\footnotetext{
${ }^{8}$ Sobre o mesmo assunto, reportar-se à análises (igualmente pertinentes e finas) de Luiz Roberto Lopez, neste dossiê sobre 1968.
} Organon, Porto Alegre, n 47, julho-dezembro, 2009, p.39- 55 
Organon, Porto Alegre, $\mathrm{n}^{\circ}$ 47, julho-dezembro, 2009, p.39 - 55 